\title{
Trichobius longipes (Diptera, Streblidae) as a parasite of Phyllostomus hastatus (Chiroptera, Phyllostomidae)
}

\author{
Trichobius longipes (Diptera, Streblidae) como parasita de Phyllostomus hastatus (Chiroptera, Phyllostomidae)
}

Carlos Eduardo Lustosa Esbérard ${ }^{1 *}$; Theany Cecilia Biavatti ${ }^{1}$; William Douglas Carvalho ${ }^{1}$; Luciana de Moraes Costa $^{1}$; Maira de Sant'Ana Godoy ${ }^{1}$; Luiz Antonio Costa Gomes ${ }^{1}$; Júlia Lins Luz ${ }^{1}$; André Pol${ }^{2}$; Edicarlos Pralon Silva

Gustavo Klotz Tato ${ }^{1}$; Gustavo Graciolli ${ }^{4}$

\author{
${ }^{1}$ Laboratório de Diversidade de Morcegos, Universidade Federal Rural do Rio de Janeiro - UFRRJ, Seropédica, RJ, Brasil \\ ${ }^{2}$ Laboratório de Mastozoologia, Universidade Federal Rural do Rio de Janeiro - UFRRJ, Seropédica, RJ, Brasil \\ ${ }^{3}$ Laboratório de Herpetologia, Universidade Federal Rural do Rio de Janeiro - UFRRJ, Seropédica, RJ, Brasil \\ ${ }^{4}$ Departamento de Biologia, Universidade Federal de Mato Grosso do Sul - UFMS, Campo Grande, MS, Brasil
}

Received March 21, 2014

Accepted July 11, 2014

\begin{abstract}
Among the factors that influence the diversity of ectoparasites on bat hosts are the kind of roost and the host's social behavior. Other factors such as sex, reproductive condition and host size may influence the distribution and abundance of ectoparasites. The aim of the present study was to analyze the variation in Streblidae ectoparasites on the bat Phyllostomus hastatus, according to sex and roost type. We caught bats in four houses on Marambaia Island, municipality of Mangaratiba, and in one house at the Federal Rural University of Rio de Janeiro, municipality of Seropédica. We caught 65 females and 50 males of P. hastatus and 664 streblids of four species: Aspidoptera phyllostomatis, Strebla consocia, Trichobius "dugesii" complex and Trichobius longipes. The species T. longipes accounted for more than $99 \%$ of all the ectoparasites caught. Female bats were more parasitized than males, in terms of both prevalence and average intensity. The total number of parasites did not vary between resident and non-resident bats. The relationship between the number of individuals of $T$. longipes and sex and roost type was significant for resident bats. The total number of parasites on males did not differ between bachelor roosts and mixed-sex roosts. The differences found between roosts reflected the differences between the sexes.
\end{abstract}

Keywords: Streblid, flies, roost, bats, sex, Southern Brazil.

\section{Resumo}

Os fatores que influenciam a diversidade de artrópodes ectoparasitos no morcego hospedeiro incluem o tipo de abrigo e o comportamento social da espécie hospedeira. Aspectos como sexo, condição reprodutiva e tamanho do hospedeiro podem influenciar a distribuição e a abundância dos ectoparasitos. Este trabalho teve como objetivo analisar a variação no parasitismo de estreblídeos em Phyllostomus hastatus, considerando os sexos e diferentes abrigos. Os morcegos foram capturados em quatro casas na Ilha da Marambaia, município de Mangaratiba, e em uma casa na Universidade Federal Rural do Rio de Janeiro, município de Seropédica. Foram capturados 65 fêmeas e 50 machos de P. hastatus e 664 dípteros estreblídeos distribuídos em quatro espécies: Aspidoptera phyllostomatis, Strebla consocia, Trichobius complexo "dugesii" e Trichobius longipes. A espécie T. longipes representou mais de $99 \%$ das capturas de Streblidae. Fêmeas de morcegos foram mais parasitadas que os machos, tanto em prevalência quanto em intensidade média. O total de parasitos não variou entre os morcegos residentes e os não residentes. $\mathrm{O}$ modelo considerado entre o total de T. longipes, o sexo e o abrigo para indivíduos residentes mostrou-se significativo. $\mathrm{O}$ total de parasitos em machos náo difere entre aqueles oriundos de abrigos de machos solteiros e de abrigos heterossexuais. As diferenças entre os abrigos refletem a diferença no parasitismo entre os sexos dos hospedeiros.

Palavras-chave: Streblidae, moscas, refúgios, morcegos, sexo, Sudeste do Brasil.

*Corresponding author: Carlos Eduardo Lustosa Esbérard, Laboratório de Diversidade de Morcegos, Universidade Federal Rural do Rio de Janeiro UFRRJ, CEP 23890-000, Seropédica, RJ, Brasil, e-mail: cesberard@superig. com.br 


\section{Introduction}

Among the factors that influence the diversity of ectoparasites on a host are roost type, roost fidelity and the host's social behavior. Ecological factors relating to the parasitism, such as infestation patterns, are some of the least studied in parasitology. Besides interspecific interactions, factors such as sex, reproductive condition and host size may influence the distribution and abundance of ectoparasites (MARSHALL, 1981).

Flies of the family Streblidae parasitize bats, mainly species of the family Phyllostomidae. These flies are viviparous; the eggs are retained in the abdomen of the female. After the larvae develop, they are deposited on the wall of the host's roost, forming pupae, from which the adults emerge after 22 to 24 days. Larviposition occurs on the wall of the roost while the bat is foraging (GRACIOLLI et al., 2008).

Some authors have tried to explain the variation in the number of streblids on their hosts, without finding significant differences between sexes (RUI; GRACIOLLI, 2005). Significant differences between sexes have only been found in some host species, such as Carollia perspicillata (Linnaeus, 1756) and Sturnira lilium (E. Geoffroy, 1810). Female C. perspicillata have higher infestation (FRITZ, 1983), whereas in S. lilium, the highest infestation occurs in juveniles (RUI; GRACIOLLI, 2005). Other authors have not observed such a relationship (e.g., KOMENO; LINHARES, 1999). According to Moura et al. (2003) in Noctilio leporinus (Linnaeus, 1758), streblid infestation did not vary with sex and age, but differed between seasons.

Phyllostomus hastatus (Pallas, 1767) is a large Neotropical bat, with body mass over $85 \mathrm{~g}$ (SANTOS et al., 2003) and forearm length over $77 \mathrm{~mm}$ (GARDNER, 2008). This species has wide distribution in South and Central America, and is absent only from Chile, Uruguay, and the islands of Central America (SANTOS et al., 2003). Females of $P$. hastatus are slightly larger than the males (SANTOS et al., 2003), and this species forms colonies composed of only bachelor males, colonies dominated by females, or harems (COSTA et al., 2010). The most frequently observed ectoparasites on P. hastatus are streblid flies (AUTINO et al., 2011; SANTOS et al., 2009; GRACIOLLI; BERNARD, 2002).

The objective of the present study was test for differences in parasitism by streblid fleas on $P$. hastatus in two different localities by sampling roosts that had been used by this bat species for many years.

\section{Materials and Methods}

The study was carried out at two sites in the state of Rio de Janeiro. The first site was located at the Evaluation Center of Marambaia Island ( $23^{\circ} 04^{\prime} \mathrm{S}$ and $\left.43^{\circ} 53^{\prime} \mathrm{W}\right)$, in the municipality of Mangaratiba. This island has an area of $42 \mathrm{~km}^{2}$ and is connected to the mainland by a $40-\mathrm{km}$ long sand spit. Part of the island is covered by forest remnants, mangrove patches and dunes (MENEZES; ARAÚJO, 2005). The region is a protected military area (Área de Proteção Ambiental de Mangaratiba - Decree 9.802 of 1987). There is a military village on the island, which occupies ca. $2.5 \mathrm{~km}^{2}$. We sampled four houses with colonies of $P$. hastatus in May 2012. All the houses had already been used by bats for several years before this study, and many of them had previously been caught and tagged. At least two bats had previously been observed roosting in these houses in samplings performed from 2010 onwards.

The second site was located on the campus of the Federal Rural University of Rio de Janeiro (UFRRJ), in the municipality of Seropédica (22 $48^{\prime} 27^{\prime \prime} \mathrm{S}$ and $\left.43^{\circ} 37^{\prime} 17^{\prime \prime} \mathrm{W}\right)$. At this site, we sampled one house with a roost in the roof lining in July 2012 , located close to experimental plantations of coffee, cocoa and bananas. A total of 94 bats were observed leaving this roost.

On Marambaia Island, we set up mist nets $(9 \times 2.5 \mathrm{~m}$, with $19 \mathrm{~mm}$ mesh) close to three houses (up to $5 \mathrm{~m}$ away from each house), and three other nets on a trail in a forest remnant. At UFRRJ, a single net was set up $1.5 \mathrm{~m}$ from the roost exit, which was unrolled before sunset and was kept open until midnight. The net was continuously checked to determine the time of capture of each bat.

Each captured bat was placed in an individual cotton bag. These bags were used only once per sampling session in order to avoid contamination, and were washed before using again. Data on sex, forearm length (resolution $=0.1 \mathrm{~mm}$ ), body mass (resolution $=1$ g) and age (ANTHONY, 1988) were analyzed for each bat. All the ectoparasites from each bat were removed by using tweezers or by hand, and were then counted and fixed in vials using alcohol ( $\left.97^{\circ} \mathrm{GL}\right)$. All flea samples were labeled concerning their hosts. Voucher specimens for the streblids were incorporated into the reference collection of the Federal University of Mato Grosso.

Each bat was tagged with an individual plastic necklace consisting of colored cylinders, following a previously determined code (ESBÉRARD; DAEMON, 1999), or with microchips (Trovan(C) and Avid(C) inserted into the dorsal region of the animal by means of a subcutaneous injection. Recaptures on the same night were not taken into consideration. Juvenile bats received only microchips and punch-marking on the dactylopatagium (BONACCORSO et al., 1976). After tagging, all the bats were released at the same site. The time when each individual was caught and the net used for this were recorded. The bats were registered according to the closest roost to the capture site. At least one researcher stayed at the roost location to observe the bats and their departure flights. We considered that bats were residents if they were observed moving from the roost to the nets and that they were non-residents if they were collected in nets set up on the trail within the forest remnant or if they were caught in nets close to houses where we did not find any roost exit.

The resident males were classified according to the type of group in which they were found: mixed-sex group - in which males and females cohabited; or bachelor group - in which only males composed the colony. One of the roosts had only two males and it was not considered in the analysis on the sex ratio.

To analyze streblid infestation on $P$. hastatus, two indexes were used: prevalence (number of infested hosts/number of examined hosts $\mathrm{x}$ 100) and average intensity of infestation (number of parasites/number of parasitized hosts) (BUSH et al., 1997). The normality of the distribution of the streblid flies at each roost was tested by means of the Shapiro-Wilk test in the Past software and alpha was taken to be significant if it was less than 0.05 . 
The Student $\mathrm{t}$ test was applied considering the total number of flies, including all the bats caught, and comparisons were made between the sexes and between the roosts. Analysis of variance was also used, and the response variable was taken to be the number of streblid flies on each bat, in relation to the factors of the sex and roost of each bat. Non-residents were excluded from this analysis. The differences in the abundance of streblid flies between resident males from mixed-sex groups and bachelor male groups were analyzed by means of the Student $t$ test. The ectoparasite abundance was calculated based only on the predominant streblid species, which corresponded to more than $99 \%$ of all the records.

\section{Results}

A hundred and fifteen specimens of $P$. hastatus (65 males and 50 females) (Table 1) were caught. Two roosts were composed of bachelor males, one roost had a predominance of males, and two roosts were mixed-sex. Despite a high proportion of bats from previous capture sessions, only one specimen was recaptured within less than 30 days. This bat was caught by hand inside the roost during the daytime and its parasites were removed. The recapture occurred 48 hours later, in a net, and this bat presented 22 new streblid flies.

A total of 664 streblids was found: one female of Aspidoptera phyllostomatis (Perty, 1833); three males and one female of Strebla consocia Wenzel, 1966, caught on two bats; one male of Trichobius of the "dugesii" complex; and 359 males and 299 females of Trichobius longipes (Rudow, 1871). Males were less parasitized by streblids than females $(\mathrm{t}=5.139, \mathrm{P}=0.001)$ (Figure 1). In males, the prevalence was lower $(47.69 \%)$ than in females $(97.06 \%)$, as was also the average intensity of infestation (males $=6.28 \pm 6.29$; females $=8.06 \pm 4.79)$. The total number of parasites did not vary between resident and non-resident bats (males: $\mathrm{t}=-1.414$, $\mathrm{P}=0.163$; females: $\mathrm{t}=-1.231, \mathrm{P}=0.224$ ).

In all the roosts, normal distribution of streblid flies was found, with values of ranging from $\mathrm{p}=0.020$ to $\mathrm{p}<0.001$. The ANOVA that was used to compare the total numbers of streblids between the sexes and the types of roosts was significant for resident bats

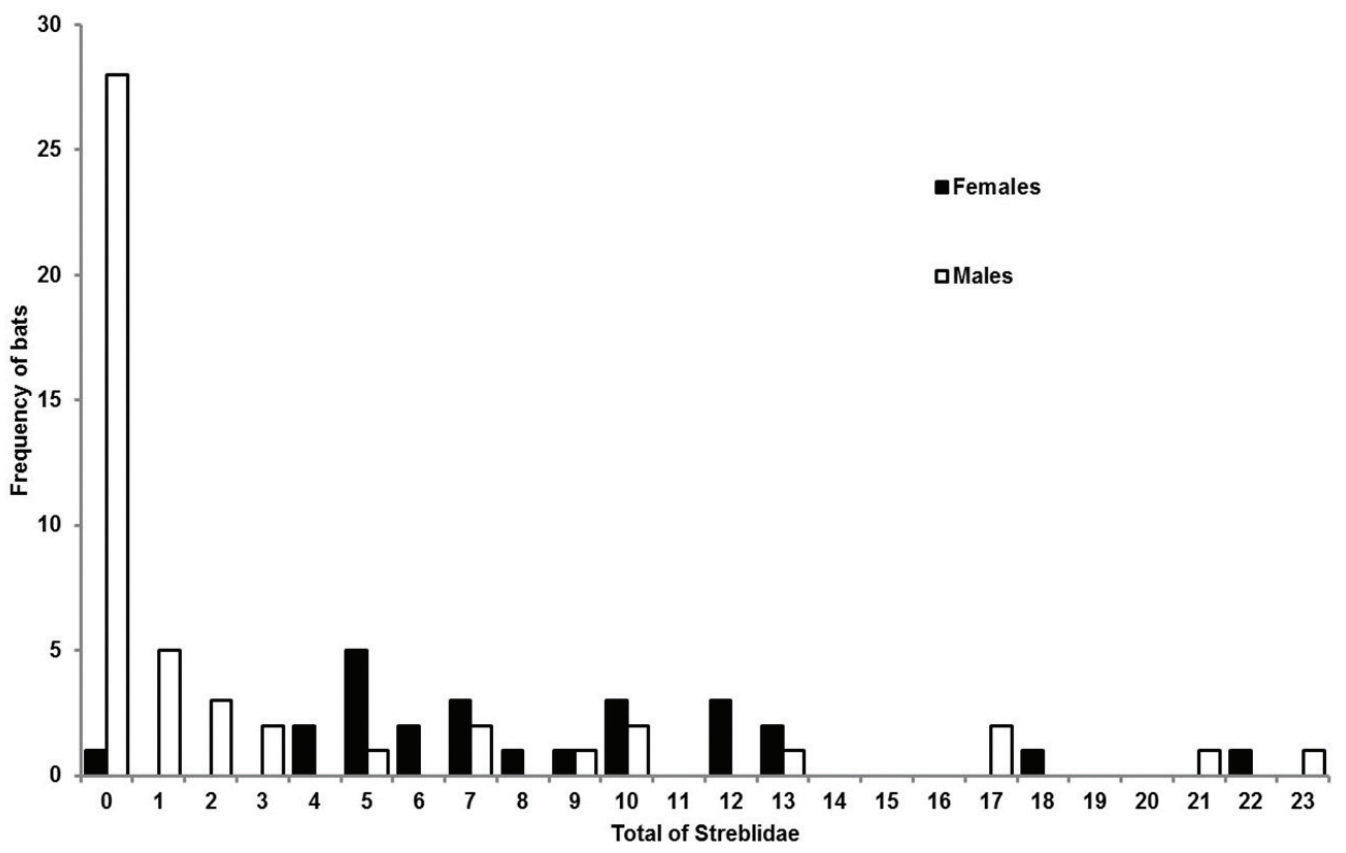

Figure 1. Numbers of streblid flies on male and female Phyllostomus hastatus bats on Marambaia Island and at the Federal Rural University of Rio de Janeiro, Brazil.

Table 1. Numbers of streblid flies, average intensity and prevalence in each roost of Phyllostomus hastatus. Non-residents refer to bats netted near the forest.

\begin{tabular}{|c|c|c|c|c|c|c|}
\hline & \multicolumn{5}{|c|}{ Roosts } & \multirow{2}{*}{ Non- residents } \\
\hline & House 1 & House 2 & House 3 & House 4 & House 5 & \\
\hline Bats leaving the roosts & $7 \hat{\sigma}$ & $2 \hat{\jmath}$ & $6{ }^{\Uparrow} 1+9$ & $3 \widehat{\jmath} 12$ 우 & $14 \hat{\bigcirc} 26$ + & $35 \hat{0} 12$ ㅇ \\
\hline Bats netted near the roosts & $4 \hat{O} 2$ 우 & - & $8 \hat{0} 1$ 우 & $13 \hat{\jmath} 7$ 우 & - & \\
\hline Ectoparasites on residents & $4(0-3)$ & 2 & $6(0-5)$ & $122(0-17)$ & $214(0-24)$ & - \\
\hline Ectoparasites on non- residents & - & - & - & - & - & $62(0-3)$ \\
\hline Intensity on residents & 2.0 & 2.0 & 3.0 & 9.83 & 6.29 & - \\
\hline Intensity on visiting bats & - & - & - & - & - & 8.86 \\
\hline Prevalence on residents $(\%)$ & 28.57 & 100.00 & 22.22 & 87.71 & 85.00 & - \\
\hline Prevalence on non- residents (\%) & - & - & - & - & - & 87.50 \\
\hline
\end{tabular}


$\left(r^{2}=0.236, F=3.574, P=0.001\right)$ (Figure 2). The total number of flies on male bats did not differ between those from bachelor roosts $(\mathrm{N}=11)$ and those from mixed-sex roosts $(\mathrm{N}=22)(\mathrm{t}=-1.630$, $\mathrm{P}=0.113$ ) (Figure 3).

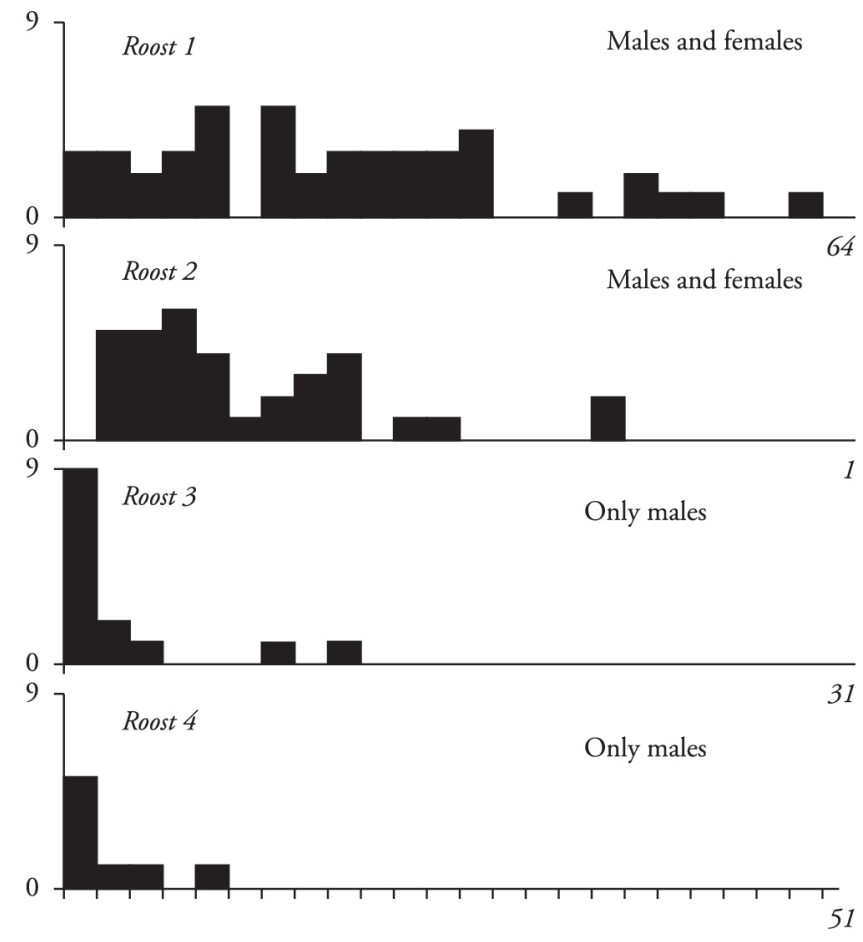

Trichobius longipes load in $P$. hastatus

Figure 2. Frequencies of streblid flies in roosts of Phyllostomus hastatus sampled on Marambaia Island and at the Federal Rural University of Rio de Janeiro, Brazil.

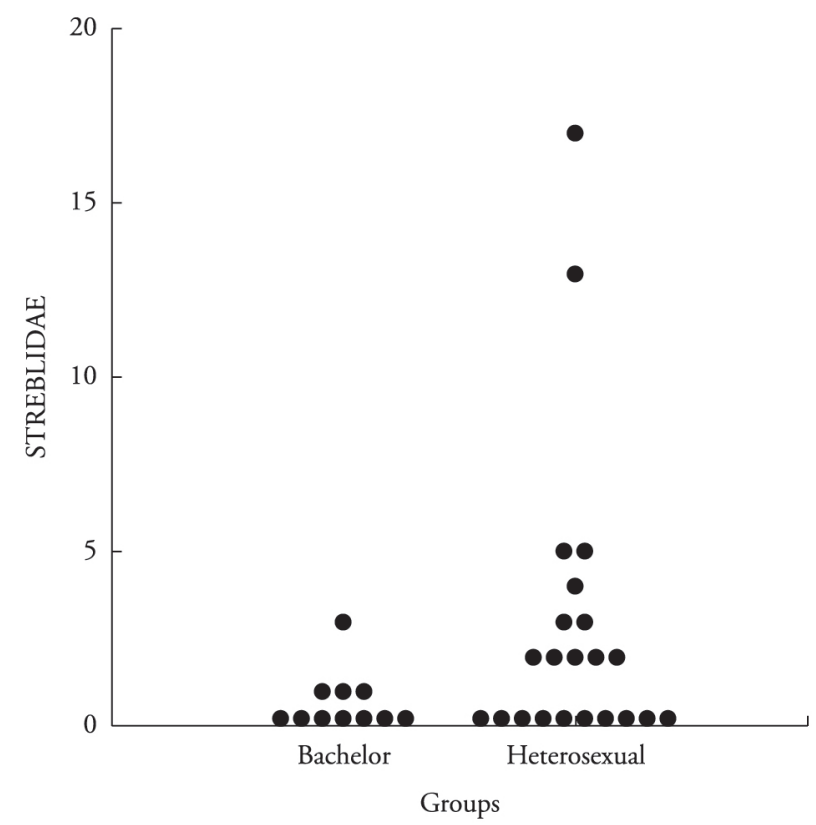

Figure 3. Numbers of streblid flies in roosts of male Phyllostomus hastatus bats, mixed-sex groups and bachelor groups.

\section{Discussion}

Females of $P$. hastatus are more parasitized than males. The difference in the parasitism of female bats has been described as resulting from their social behavior (KRASNOV et al., 2012). However, a bias towards males is more frequent in other mammals. Male rodents are more mobile and have larger home ranges, which leads to higher infestation (KRASNOV et al., 2012). A parasitism bias towards females was observed in bats of the genus Myotis, which live in aggregates, with males roosting alone (CHRISTE et al., 2007). Another hypothesis to explain the bias toward females is the high concentration of androgens in males, which could lead to better development of flies on female than on male hosts (CHRISTE et al., 2007).

Reproductive seasonality cannot explain the bias observed in the present study, because the sampling was restricted to periods of reproductive inactivity at the latitude studied. Males and females of $P$. hastatus do not differ much in size, so size alone cannot explain the large difference observed (SANTOS et al., 2003). Besides, this species lives long in comparison with rodents, whose males live less than females (KRASNOV et al., 2012).

Females of $P$. hastatus have broader interspecific interactions and higher roost fidelity (MCCRAKEN; BRADBURY, 1981). Harems are stable, with females living together for consecutive years, whereas long cohesion has not been observed in bachelor groups. However, even males form clusters (COSTA et al., 2010), and therefore aggregation does not explain the higher infestation observed on females. Long permanence in the same roost may result in higher infestation (LEWIS, 1995; RECKARDT; KERTH, 2006, 2007; PATTERSON et al., 2007). Females showing fidelity to the same roost and group and present in all seasons of the year enable greater survival of flea populations than do males that change roosts more frequently (MCCRAKEN; BRADBURY 1977). This strategy may assure different parasite infestation between the sexes.

Since females have more parasites than males, males that maintain permanent contact with females should have a higher load of Streblidae. However, males caught in mixed-sex roosts did not differ from males caught in bachelor colonies, regarding the total number of streblids. Hence, female bats must be preferred by streblids, as already observed by Krasnov et al. (2012), and even males with permanent contact with females would therefore not have more parasites.

Since roosts may have different sex ratios (MCCRAKEN; BRADBURY, 1981; COSTA et al., 2010), different prevalence and intensity values may be observed, as in the present study. Constant roost changes may also be responsible for re-infestation and dispersal of ectoparasites within the bat population. The only bat recaptured during this study, a male that was caught 48 $\mathrm{h}$ before recapture, came from a bachelor roost and carried three specimens of T. longipes. This bat was recaptured close to a mixedsex roost, carrying 22 specimens of $T$. longipes. This evidence of fast re-infestation was probably related to a roost change. The difference found between roosts reflects the composition of each bat colony: prevalence and abundance are higher in groups that contain females. 


\section{Acknowledgements}

We thank Centro de Avaliação da Ilha da Marambaia and UFRRJ for their support and for the collection permit and E. Valle, A. Pedrozo, S. Oliveira, N. Araújo and A.M. Boffy for helping in fieldwork. The present study was developed under a special collection permit granted by IBAMA-DF (SISBIO 10356-1 granted to C.E.L. Esbérard). L. M. Costa received a $\mathrm{PhD}$ scholarship from Fundação Carlos Chagas Filho de Amparo à Pesquisa do Estado do Rio de Janeiro - FAPERJ (Bolsa Nota 10). W.D. Carvalho received a PhD scholarship from Coordenação de Pesquisa e Ensino (CAPES). J.L. Luz received a PhD scholarship from Conselho Nacional de Desenvolvimento Científico e Tecnológico (CNPq). T. Biavatti, M.S.M. Godoy, L.A.C. Gomes and E. Pralon received MSc. scholarships from CAPES. C.E.L. Esbérard received a research productivity fellowship from $\mathrm{CNPq}$ (process 152910/2004-0) and a JCNE fellowship from FAPERJ (process E-26/102.201/2009).

\section{References}

Anthony ELP. Age determination in bats. In: Kunz TH. Ecological and behavioral methods for the study of bats. Washington: Smithsonian Institution; 1988. p. 47-58.

Autino AG, Claps GL, Barquez RM, Díaz MM. Ectoparasitic insects (Diptera: Streblidae and Siphonaptera: Ischnopsyllidae) of bats from Iquitos and surrounding areas (Loreto, Peru). Mem Inst Oswaldo Cruz 2011; 106(8): 917-925. PMid:22241111. http://dx.doi.org/10.1590/ S0074-02762011000800004

Bonaccorso FJ, Smythe N, Humphrey RS. Improved techniques for marking bats. J Mammal 1976; 57(1): 181-182. http://dx.doi. org/10.2307/1379526

Bush AO, Lafferty KD, Lotz JM, Shostak AW. Parasitology meets ecology on it own terms: Margolis et al. revisited. J Parasitol 1997; 83(4): 575583. PMid:9267395. http://dx.doi.org/10.2307/3284227

Christe P, Glaizot O, Evanno G, Bruyndonckx N, Devevey G, Yannic G, et al. Host sex and ectoparasites choice: preference for, and higher survival on female hosts. J Anim Ecol 2007; 76(4): 703-710. PMid:17584376. http://dx.doi.org/10.1111/j.1365-2656.2007.01255.x

Costa LM, Lourenço EC, Esbérard CEL, Silva RM. Colony size, sex ratio and cohabitation in roosts of Phyllostomus hastatus (Pallas) (Chiroptera: Phyllostomidae). BrazJ Biol 2010; 70(4): 1047-1053. PMid:21180912. http://dx.doi.org/10.1590/S1519-69842010000500019

Esbérard CEL, Daemon C. Novo método para marcação de morcegos. Chirop Neotrop 1999; 5(1-2): 116-117.

Fritz GN. Biology and ecology of bat flies (Diptera: Streblidae) on bats in the genus Carollia. J Med Entomol 1983; 20(1): 1-10. PMid:6827567.

Gardner, A. L. Order Chiroptera. In: Gardner AL. Mammals of South America. Chicago: University of Chicago Press; 2008. vol. 1. Marsupials, xenarthrans, shrews and bats. p. 187-484.

Graciolli G, Azevedo AA, Arzua M, Barros-Battesti DM, Linardi PM. Artrópodos ectoparasitos de morcegos no Brasil. In: Pacheco SM, Marques RV, Esbérard CEL. Morcegos do Brasil: biologia, sistemática, ecologia e conservação. Porto Alegre: Armazém Digital; 2008. p. 123-138.
Graciolli G, Bernard E. Novos registros de moscas ectoparasitas (Diptera, Streblidae e Nycteribiidae) em morcegos (Mammalia, Chiroptera) do Amazonas e Pará, Brasil. Rev Brasil Zool 2002; 19(S1): 77-86. http:// dx.doi.org/10.1590/S0101-81752002000500003

Komeno CA, Linhares AX. Batflies parasitic on some phyllostomid bats in Southeastern Brazil: parasitism rates and host-parasite relationships. Mem Inst Oswaldo Cruz 1999; 94(2): 151-156. http://dx.doi.org/10.1590/ S0074-02761999000200004

Krasnov BR, Bordes F, Khokhlova IS, Morand S. Gender-biased parasitism in small mammals: patterns, mechanisms, consequences. Mammalia 2012; 76(1): 1-13. http://dx.doi.org/10.1515/mammalia-2011-0108

Lewis SE. Roost fidelity in bats: a review. J Mammal 1995; 76(2): 481496. http://dx.doi.org/10.2307/1382357

Marshall AG. The ecology of ectoparasitic insects. London: Academic Press; 1981.

McCraken GF, Bradbury JW. Paternity and genetic heterogeneity in the polygynous bat, Phyllostomus hastatus. Science 1977; 198(4314): 303306. PMid:17770506. http://dx.doi.org/10.1126/science.198.4314.303

McCracken GF, Bradbury JW. Social organization and kinship in the polygynous bat Phyllostomus hastatus. Beh Ecol Sociobiol 1981; 8(1): 1134. http://dx.doi.org/10.1007/BF00302840

Menezes LFT, Araújo DSD. Formaçóes vegetais da restinga da Marambaia. In: Menezes LFT, Peixoto AL, Araújo DSD. História natural da Marambaia. Rio de Janeiro: Universidade Federal Rural do Rio de Janeiro; 2005. p. 67-120.

Moura MO, Bordignon MO, Graciolli G. Host characteristics do not affect community structure of ectoparasites on the fishing bat Noctilio leporinus (L., 1758) (Mammalia: Chiroptera). Mem Inst Oswaldo Cruz 2003; 98(6): 811-815. PMid:14595460. http://dx.doi.org/10.1590/ S0074-02762003000600017

Patterson BD, Dick CW, Dittmar K. Roosting habits of bats affect their parasitism by bat flies (Diptera: Streblidae). J Trop Ecol 2007; 23(2): 177-189. http://dx.doi.org/10.1017/S0266467406003816

Reckardt K, Kerth G. The reproductive sucess of the parasitic bat fly Basilia nana (Diptera: Nycteribiidae) is affected by low roost fidelity of its host, the Bechstein's bat (Myotis bechsteinii). Parasitol Res 2006; 98(3): 237-243. PMid:16341882. http://dx.doi.org/10.1007/s00436005-0051-5

Reckardt K, Kerth G. Roost selection and roost switching of female Bechstein's bats (Myotis bechsteinii) as a strategy of parasite avoidance. Oecologia 2007; 154(3): 581-588. PMid:17805579. http://dx.doi. org/10.1007/s00442-007-0843-7

Rui AM, Graciolli G. Moscas ectoparasitas (Diptera, Streblidae) de morcegos (Chiroptera, Phyllostomidae) no sul do Brasil: associaçōes hospedeiros-parasitos e taxas de infestação. Rev Brasil Zool 2005; 22(2): 438-445. http://dx.doi.org/10.1590/S0101-81752005000200021

Santos M, Aguirre LF, Vázquez LB, Ortega J. Phyllostomus hastatus. Mammalian Species 2003; 722(1): 1-6. http://dx.doi.org/10.1644/722

Santos CLC, Dias PA, Rodrigues FS, Lobato KS, Rosa LC, Oliveira TG, et al. Moscas ectoparasitas (Diptera: Streblidae) de morcegos (Mammalia: Chiroptera) do Município de São Luís, MA: taxas de infestação e associações parasito-hospedeiro. Neotrop Entomol 2009; 38(5): 595-601. PMid:19943006. http://dx.doi.org/10.1590/S1519566X2009000500006 